\title{
The Influence of School Head Management and Teacher Success of Student Learning Outcomes in SMP Negeri 01 Muaradua Kisam, Oku Selatan District
}

\author{
Muhammad Suharni ${ }^{1 *}$, Yasir Arafat ${ }^{2}$, Yenny Puspita ${ }^{2}$ \\ ${ }^{1}$ SMP Negeri 01 Muaradua Kisam Oku Selatan District, South of Sumatra, Indonesia \\ ${ }^{2}$ Universitas PGRI Palembang, Indonesia \\ ${ }^{*}$ Corresponding author. Email: muh.suharni@gmail.com
}

\begin{abstract}
The goal of this study was to define and explain the impact of core management on learning outcomes, the impact of teacher performance on learning outcomes and the impact of core management and teacher performance on learning outcomes. This research uses a quantitative approach to data collection methods using questionnaires, documentation, in-depth interviews and data management using the SPSS formula, the findings of this study suggest that the management of the principal has an effect on student learning outcomes at SMP Negeri 01 Muaradua Kisam, OKU Selatan District, the performance of the teacher affects the results. Student learning at SMP Negeri 01 Muaradua Kisam, OKU Selatan District and senior management and teacher success jointly affect student learning outcomes at SMP Negeri 01 Muaradua Kisam, OKU Selatan District.
\end{abstract}

Keywords: School Head Management, Teacher Success, Student Learning Outcomes

\section{INTRODUCTION}

National education functions to build and form the character and society of the country, with the goal of improving the capacity of students to become human beings who believe and have faith in God the Almighty. The educational process is a public process [1]. The goal of national education is to improve human quality as quickly as possible in a targeted, coordinated and comprehensive way, through a variety of constructive and innovative initiatives by all components of the country, so that the younger generation can develop in an optimal way. This language is consistent with the Constitution of 1945, which stresses that the government is pursuing and enforcing a national teaching system that is governed by law. The responsibility of the school shall be exercised by the Government and the private institutions which have been determined by a Government Decree. Schools are structured organizations responsible for establishing what is prescribed by the Legislation on the National Education System.

The leader must be able to motivate the members of the community to work fully with a sense of duty, and the leader is required to have the capacity and strength to: (1) the ability and strength to think about running the organization or working group he leads; (2) personal strengths, particularly those related to enthusiasm, tenacity, bravery, wisdom and justice, trust, warmth, stability of emotion, integrity, humility, modesty and discipline; (3) knowledge advantages, especially in policy-making, comprehension and understanding of the actions and job satisfaction of the teachers or subordinates they lead. The Principal has the authority and policies to enhance the standard of education as a leader [2]. In carrying out its duties, the Principal can use certain techniques to ensure that the objectives set can be effectively achieved. This technique will be reflected in the leadership action that is carried out by guiding and manipulating the people they lead [3].

The School Head has a very important role so that the Principal must have the capacity and willingness to control, inspire, invite, guide, mobilize, direct and then do something that will help to achieve a predetermined objective. In the field of education, according to Wahab, [4] leadership means: "The ability or power to move the education implementers in order to achieve the educational goals that have been set effectively and efficiently" As the chief in education, the principal has a strong burden. The School Head should be able to carry out innovations and be able to lead all stakeholders and the school as an educational institution [5]. 
The School Head, as the leader of an educational institution, has a significant role to play in establishing a favorable climate in his work environment. Through the leadership style that a leader will be able to transfer some values [6]. This favorable environment is an important factor in the development of outstanding teachers. Teachers, as educators, have a very important role to play in the development of the country, and teachers are one of the main factors in the success of education. "Education personnel, especially teachers, are the soul of the school." Thus, an increase in the professionalism of education personnel, starting from needs analysis, preparation, growth, performance appraisal, labor relations to remuneration, is an essential work for the principal.

The theory is one of the components of education that plays the most part in enhancing the standard of education. In the sense of regional autonomy and decentralization of education, the phase of human resources growth must include different fields of life that must be represented in the staff of leaders, including educational leaders, such as school principals. Improving the quality of human capital, particularly as a school leader in education, is therefore a demand for improving the quality of education [7].

As a chief, the Principal must be able to provide direction and oversight, enhance communication and delegate tasks. Communication abilities will be expressed in their ability to interact orally with school staff and students, to convey ideas in writing, and to build a pleasant environment for teachers and students. In addition, the school principal must also be in a position to have a strong interpersonal relationship with his subordinates in his management style.

A school principal must be able to set an example and protect his or her subordinates, inspire and motivate them so that everybody can and wishes to function optimally in compliance with the job descriptions he or she has provided and works honestly and with complete accountability to increase student learning achievement.

Teachers have a very important role to play in assessing the standard of school graduates. Suitable teaching also could make significant graduates [8]. This means that teachers of the highest standard and achievement are required to produce quality graduates. In the meantime, teachers of the highest standard and achievement can be achieved if they are assisted by good leadership. Teacher is one of the human components of the teaching and learning process that plays a role in the creation of future human capital. Accordingly, according to Sardiman [9] it is reported that: "The teacher is one of the elements in the field of education must play an active role and position as a professional, in accordance with the demands of a growing society"
High performance of the teacher is a manifestation of the efficiency of the teacher. This is very important to achieve the objectives of the school. High performance ensures that teachers will act as educators that are effective and effective in keeping with the objectives that they want to accomplish. If the objective of improving the performance of teachers can be accomplished, the objective of improving the standard of education can be properly achieved.

Student achievement shall be included in the context of school production. According to Rohiat [10], school success includes educational production. School success is student achievement that is the product of school processes/behavior. School success can be calculated by quality, reliability, productivity, efficiency, creativity, working life and job morality. Specifically on the quality/quality of school performance, it can be clarified that school output is said to be of high quality/quality if student achievement, in particular student achievement, is seen to be of high quality/quality: (1) academic achievement in the form of regular test scores, portfolio scores, grades General tests or mastery completion, National Student Final Exams/National Examinations, scientific articles, academic competitions, other student works; (2) non-academic achievements such as Faith Taqwa, integrity, politeness, sports, arts, technical skills, and so on. The standard of the school is determined by several interconnected phases of operation (processes) such as planning, execution and supervision.

Nurkolis [11] argues that schools must have the expected output. The output of the school is the Student Achievement, which is produced by the learning and management process in schools. In general, output can be categorized into two categories, namely output in the form of academic achievement and output in the form of non-academic achievement. The output of academic achievement is, for example, NEM, youth science work competitions, competitions (Arabic, English, Mathematics, Science), ways of thinking (critical, creative/diversary, rational, rational, inductive, deductive, and scientific). Non-academic output, such as high curiosity, self-esteem, honesty, good cooperation, a high level of affection for others, high solidarity, tolerance, discipline, diligence, sporting achievements, the arts, and scouting.

According to Rivayanti et al [12] in the Community of Innovation in Teaching and Instructional Media 2020 with the title "Principal Leadership Management in Fostering Teacher Professionalism" It is said that the professionalism of teachers is very important to become the basic principles underpinning the core activities of educational institutions, namely the learning process. However, the low quality of teachers is one of the biggest problems in the world of education. Quality teachers are, in fact, one of the most important 
components in determining the success of achieving educational objectives.

Learning objectives are not easy to achieve, because there are many problems that need to be addressed in the learning process, so that not a few teachers are sometimes trapped in a task that has only short-term objectives, as a result of which problems that are more essential for teachers are often ignored.

SMP Negeri 01 Muaradua Kisam has been formed since 1982, aged in Muaradua Kisam District. SMP Negeri 01 Muaradua Kisam has changed its leadership many times and has also graduated a number of students. Along with the progression of the times, this school has gained many milestones with the school accreditation being A. This, of course, is a positive thing about the standard of graduates and school management. To further explore this, researchers are more interested in conducting research under the title "The Effect of Principal Management and Teacher Performance on Student Learning Outcomes at State Junior High School 01 Muaradua Kisam, Oku Selatan District."

\section{METHODS}

The position of this research is in the SMP Negeri 01 Muaradua Kisam Ogan Komering Ulu Selatan environment. Address: Jalan Tebat Limau, Dusun Tengah Village, Muaradua Kisam Subdistrict. The research phase began in October 2020 and ended in December 2020. This analysis is an empirical observational study in which the researcher makes direct statements to the respondents by circulating questionnaires to be evaluated using quantitative research methods. Sample selection is related to how to choose respondents who can provide accurate and reliable information in order to obtain the necessary data. The place of this research operation was at SMP Negeri 01 Muaradua Kisam Ogan Komering Ulu Selatan.

Population is a generalization region made up of items or subjects having certain quantities and characteristics that are decided by the researchers to study and then to draw conclusions [13]. The population of this study was the teachers of the SMP Negeri 01 Muaradua Kisam Ogan Komering Ulu Selatan, with 39 students, 300 students, the questionnaire data collection technique was given to the respondents, namely the teachers of the SMP Negeri 01 Muaradua Kisam South Komering Ulu on the Impact of Principal Management and Teacher Performance on Student Learnin. The preparation of alternative answers to this questionnaire is based on a model of the Likert scale. Likert is used to assess the behaviors, beliefs and expectations of an individual or group regarding social events or symptoms. In science, this social phenomenon has been explicitly defined by the researcher, hereinafter referred to as the research variable: 1) observation, is a tool for the collection of naturalistic research data that takes place in a natural context. The researcher's findings were in the context of evaluating the behaviors of teachers while teaching at school and reporting on student learning outcomes; 2) study of documents, Sugiyono Documentation [13] is a tool used to collect data and knowledge in the form of books, files, records, written numbers and photographs in the form of reports and information that can help analysis. The documentation approach used in this study is the primary data in the form of student learning results reports (Raport).

\section{RESULTS AND DISCUSSION}

\section{Multiple Regression Analysis}

$$
Y=4,953+0,250 X_{1}+0,504 X_{2}
$$

The results of the multiple regression equation can be interpreted to mean that the constant is 4,953 , which means that if the main management and teacher performance are absent or the value is 0 (zero), then the student learning outcomes at SMP Negeri 01 Muaradua Kisam, OKU Selatan District, are 4,953. The regression coefficient with the main management variable $\left(\mathrm{X}_{1}\right)$ is 0.250 , which means that if the principal's management is increased by 1 unit, the student learning outcomes will experience a significant increase of 0.250 , assuming that other variables are of fixed value. The coefficient is positive, which means that if the management of the principal increases, the learning outcomes of students at SMP Negeri 01 Muaradua Kisam, OKU Selatan District will also increase. The regression coefficient with the teacher performance variable $\left(\mathrm{X}_{2}\right)$ is 0.504 , which means that if the teacher performance is increased by 1 unit, the student learning outcomes will experience a significant increase of 0.504 , assuming that other variables are of a fixed value. The coefficient is positive, which means that if the performance of the teacher increases, the learning outcomes of the students at SMP Negeri 01 Muaradua Kisam, OKU Selatan District will also increase.

\section{Hypothesis testing}

\section{a. T test}

1) The Influence of Principal Management on Student Learning Outcomes 
Table 1. Results of Testing $X_{1}$ on $Y$

\begin{tabular}{|l|l|l|l|l|}
\hline Koefisien Jalur & $\mathbf{t}_{\text {hitung }}$ & $\mathbf{t}_{\text {tabel }}$ & $\mathbf{S i g}$ & Ket \\
\hline 0,250 & 2,245 & 2,028 & 0,031 & Take effect \\
\hline
\end{tabular}

Based on Table 3.1, it can be seen that $t_{\text {count }}$ is $2.245>\mathrm{t}_{\text {table }}$ is 2.028 and a significant value is 0.031 $<0.05$ because $\mathrm{t}$ count is greater than $\mathrm{t}$ table, so it was decided to reject $\mathrm{H} 0$ at a significance level of 0.031 . Based on the test results, therefore, the management of the principal has an effect on student learning outcomes at SMP Negeri 01 Muaradua Kisam, OKU Selatan District.

2) The Influence of Teacher Success on Student Learning Outcomes

Table 2. Table 1. Results of Testing $X_{2}$ on $Y$

\begin{tabular}{|l|l|l|l|l|}
\hline Koefisien Jalur & $\mathbf{t}_{\text {hitung }}$ & $\mathbf{t}_{\text {tabel }}$ & Sig & Ket \\
\hline 0,504 & 3,066 & 2,028 & 0,004 & Take effect \\
\hline
\end{tabular}

On the basis of Table 3.2 it can be seen that $t_{\text {count }}$ is $3.066>\mathrm{t}_{\text {table }}$ is 2.028 and a significant value is 0.004 $<0.05$ because $t_{\text {count }}$ is greater than $t_{\text {table, }}$, then with a significance level of 0.004 it was decided to reject $\mathrm{H} 0$. Thus, based on the test results, it shows that teacher performance affects student learning outcomes at SMP Negeri 01 Muaradua Kisam, OKU Selatan District.
The $\mathrm{F}$ test is used to determine whether the independent variable is significant or not at the same time as the dependent variable, namely: 'Principal Management $\left(\mathrm{X}_{1}\right)$ and Teacher Performance $\left(\mathrm{X}_{2}\right)$ on the dependent variable, namely Student Learning Outcomes at Muaradua 01 Muaradua Junior High School, Muaradua Kisam Ogan Komering Ulu Selatan (Y).

\section{b. F-test}

Table 3. Results of Testing $X_{1}$ and $X_{2}$ on $Y$

\begin{tabular}{|l|l|l|l|}
\hline $\mathbf{F}_{\text {hitung }}$ & $\mathbf{F}_{\text {tabel }}$ & Sig & Ket \\
\hline 29,577 & 3,252 & 0,000 & Take effect \\
\hline
\end{tabular}

Based on Table 3. the effects of the F test study can be clarified together or at the same time that the two key management variables $\left(\mathrm{X}_{1}\right)$ and the teacher success variable $\left(\mathrm{X}_{2}\right)$ together or simultaneously affect the student learning outcomes variable (Y) in SMP Negeri 01 Muaradua Kisam, OKU Selatan District. This is demonstrated by the acquisition of the Fcount value of 29.577, which is greater than the Ftable value of 3.252 with a lower value than the alpha value $(0.05)$, which is equal to 0.000 .

\section{c. Coefficient of concept}

The test results of the coefficient of determination $\left(R_{2}\right)$ can be seen from the coefficient of determination shown in Table 4. below:

Table 4. Result of Determination Coefficient Test $\left(\mathbf{R}_{2}\right)$

\begin{tabular}{|l|l|l|l|l|}
\hline \multicolumn{5}{|c|}{ Model Summary $^{\mathbf{b}}$} \\
\hline Model & $\mathrm{R}$ & R Square & Adjusted R Square & Std. Error of the Estimate \\
\hline 1 & $.788^{\mathrm{a}}$ & .622 & .601 & 5.625 \\
\hline \multicolumn{5}{|c|}{ a. Predictors: (Constant), Management Outcomes, Teacher Success } \\
\hline
\end{tabular}

Based on Table 4. above, it is also understood that the coefficient of determination (Adjusted R Square) is 0.622 , which means that 62.2 per cent of the improvement in student learning outcomes variables is due to principal management and teacher results, while the remaining 37.8 per cent is due to other factors such as variable instances. Students' interest in learning, desire to learn, learning, and others.

\section{CONCLUSION}

Based on the results of the study, it can be concluded that: a) head school management affects student learning results at SMP Negeri 01 Muaradua Kisam, OKU Selatan District; b) teacher performance affects 
student learning outcomes in SMP Negeri 01 Muaradua Kisam, OKU Selatan District, and 3) head school management and teacher success jointly affect student learning outcomes at SMP Negeri 01 Muaradua Kisam, OKU Selatan District.

\section{ACKNOWLEDGMENTS}

The author would like to thank Dr. H. Bukman Lian, M.M., M.Si., Chancellor of the PGRI Palembang University, Dr. Syaiful Eddy, M.Sc., Director of the Postgraduate Program at the PGRI Palembang University, Dr. Happy Fitria, M.Pd., Head of Education Management Study Program and all those who have helped morally and materially. May the goodness become multiple good deed.

\section{REFERENCES}

[1] Maseleno, A., Ayshwary, B., Ivanova, T. N., Hashim, W., Nguyen, P. T., Shankar, K., Kristiawan, M., Huda, M. (2019). General Theoretical and Philosophical Aspects of Modern Education. Aspectos Teóricos y Filosóficos Generales de la Educación Moderna. Revista San Gregorio 2019, No. 32 Special Issues August.

[2] Asvio, N., Yamin, M., \& Risnita. (2019). Influence of Leadership Style, Emotional Intelligence and Job Satisfaction toward Organizational Commitment (Survey at SMA Muhammadiyah South Sumatera). International Journal of Scientific \& Technology Research 8 (8).

[3] Mantja, W. (2007). Etnografi Desain Penelitian Kualitatif Pendidikan dan Manajemen Pendidikan [Ethnography of Educational Qualitative Research Design and Educational Management]. Malang: Elang Mas.

[4] Wahab, A. S. (2008). Analisis Kebijaksaan dari formulasi ke implementasi kebijaksanaan negara [Policy Analysis from formulation to implementation of state policies]. Jakarta: Bumi Aksara.

[5] Andriani, S., Kesumawati, N., \& Kristiawan, M. (2018). The Influence of the Transformational Leadership and Work Motivation on Teachers Performance. International Journal of Scientific \& Technology Research, 7(7).

[6] Ruslan, Lian, B., \& Fitria, H. (2020). The Influence of Principal's Situational Leadership and Teacher's Professionalism on Teacher's Performance. International Journal of Progressive Sciences and Technologies (IJPSAT), 20(1). Retrieved from https://ijpsat.ijsht-

journals.org/index.php/ijpsat/article/view/1733
[7] Mulyasa, E. (2007). Standar Kompetensi dan Sertifikasi Guru [Competency Standards and Teacher Certification]. Bandung: PT. Remaja Rosdakarya

[8] Hanim, H., \& Rahmadoni, J. (2020). Determination of Lecturer Reception Using Analytical Hierarchy Process (AHP). Journal of Applied Engineering and Technological Science (JAETS), 1 (2), 136141.

[9] Sardiman, A. M. (2010). Interaksi dan Motivasi Belajar Mengajar [Teaching and Learning Interaction and Motivation]. Jakarta: PT Raja Grafindo.

[10] Rohiat. (2008). Manajemen Sekolah - Teori Dasar dan Praktik Dilengkapi dengan Contoh Rencana Strategis dan Rencana Operasional pSchool Management - Basic Theory and Practice Equipped with Examples of Strategic Plans and Operational Plans]. Bandung: PT. Refika Aditama.

[11] Nurkholis. (2006) Manajemen Berbasis Sekolah [School Based Management]. Jakarta: Grasindo.

[12] Rivayanti, Arafat, Y., \& Puspita, Y., (2020). Manajemen Kepemimpinan Kepala Sekolah dalam Pembinaan Profesionalisme Guru. Journal of Innovation in Teaching and Instructional Media, 1(1), 10-17. Retrieved from http://ejournal.karinosseff.org/index.php/jitim/articl e/view/25

[13] Sugiyono. (2004). Metode Penelitian [Research Methods]. Bandung: Alfabeta. 